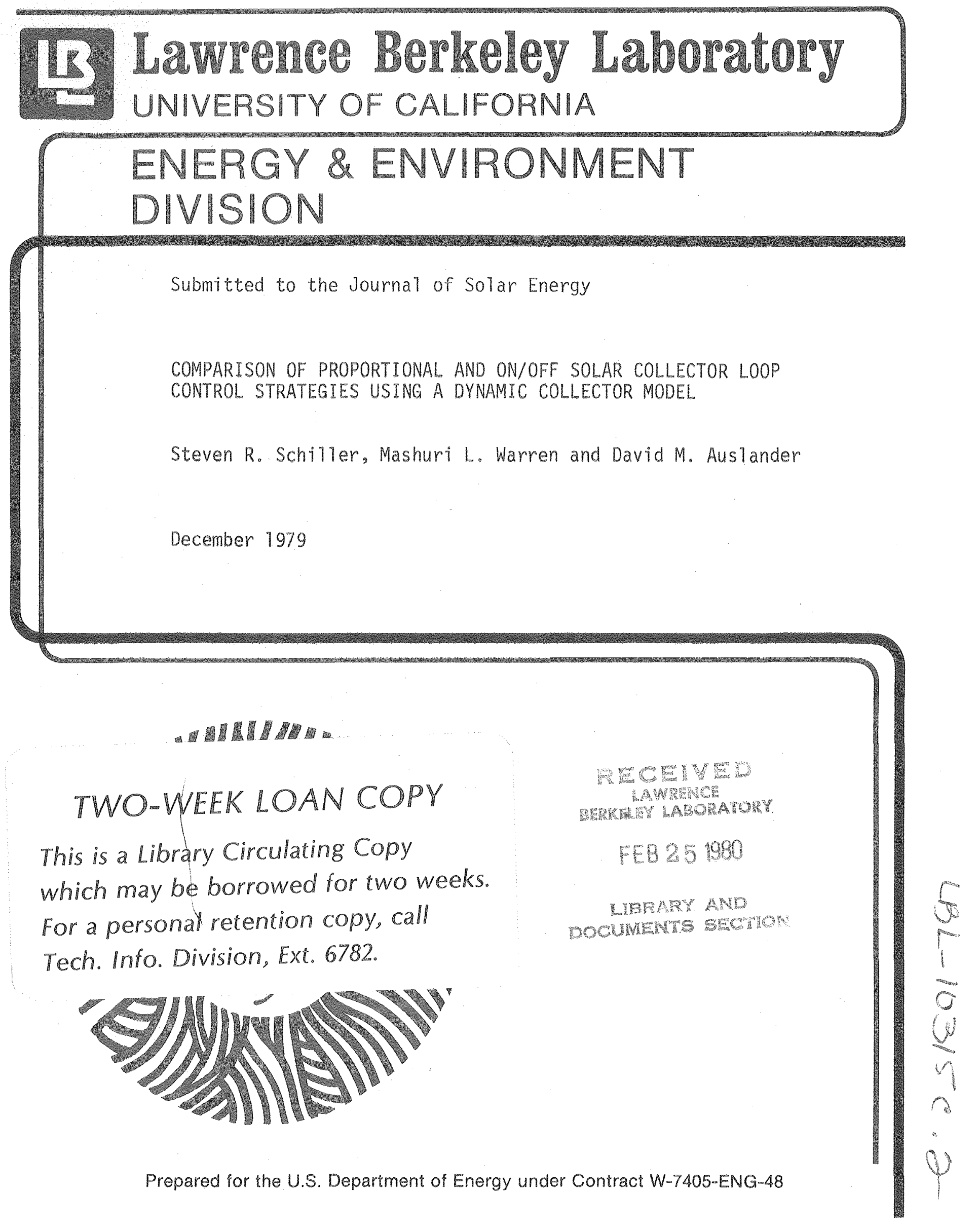




\section{DISCLAMTR}

This document was prepared as an account of work sponsored by the United States Government. While this document is believed to contain correct information, neither the United States Government nor any agency thereof, nor the Regents of the University of California, nor any of their employees, makes any warranty, express or implied, or assumes any legal responsibility for the accuracy, completeness, or usefulness of any information, apparatus, product, or process disclosed, or represents that its use would not infringe privately owned rights. Reference herein to any specific commercial product, process, or service by its trade name, trademark, manufacturer, or otherwise, does not necessarily constitute or imply its endorsement, recommendation, or favoring by the United States Government or any agency thereof, or the Regents of the University of California. The views and opinions of authors expressed herein do not necessarily state or reflect those of the United States Government or any agency thereof or the Regents of the University of California. 


\title{
COMPARISON OF PROPORTIONAL AND ON/OFF SOLAR COLLECTOR LOOP CONTROL STRATEGIES USING A DYNAMIC COLLECTOR MODEL
}

\author{
Steven R. Schiller and Mashuri Lo Warren \\ Solar Group \\ Energy and Environment Division \\ Lawrence Berkeley Laboratory \\ University of California, Berkeley \\ and David M. Auslander \\ Department of Mechanical Engineering \\ University of California, Berkeley
}

ABSTRACT

\begin{abstract}
Common control stracegies used to regulate the flow of liquid through flat-plate solar collectors are discussed and evaluated using a dynamic collector model. Performance of all strategies is compared using different set points, flow rates, insolation levels and patterns (clear and cloudy days), and ambient temperature conditions.

The unique characteristic of the dynamic collector model is that it includes effects of collector capacitance. In general, capacitance has a minimal effect on long term collector performance; however, short term temperature response and the energy -storage capability of collector capacitance are shown to play significant roles in comparing on/off and proportional controllexs. Inclusion of these effects has produced considerably more realistic simulations than any generated by steady-state models.
\end{abstract}

Simulations indicate relative advantages and disadvantages of both types of controllers, conditions under which each performs better, and the importance of pump cycling and controller set points on total energy collection.

Results show that the turn-on set point is not always a critical factor in energy collection since collectors store energy while they warm up and during cycling; and, that proportional flow controllers

$[*]$ This work has been supported by the systems Analysis and Design Branch, Systems Development Division, Office of Solar Applications, U.S. Department of Energy, under Contract No. W-7405-ENG-48. 
provide improved energy collection only during periods of interrupted or very low insolation when the maximum possible energy collection is relatively low. Although proportional controllers initiate flow at lower insolation levels than on/off controllers, proportional controllers produce lower flow rates and higher average collector temperatures resulting in slightly lower instantaneous collection efficlencies.

\section{1) INTRODUCTION}

Active solar heating systems are generally capital intensive; therefore, improvements which increase system efficiency must do so with only a small incremental initial cost in order for them to help solar energy compete with other energy sources. Since improved control systems and strategies may satisfy thls criterion, researchers and manufacturers have sought to evaluate and improve system controllers.

Comercially available controllers for domestic heating systems include both on/off and proportional feedback control[41]. While some manufacturers have advertised microprocessor based control systems, none of these systems are applicable, as yet, for residential solar energy usage. On/off controllers have had the widest application due to their simplicity and generally reliable operation. However, demonstration projects $[5,8,25,36]$ have shown that two problems can occur with these controllers: 1) they can cause the circulating pump to cycle on and off excessively and 2) improper selection of set points can cause low system efficiency. In response to these problems some controller manufacturers have marketed proportional flow controllers, claiming improved overall system efficiencies.

With the exemption of the work at Drexel Universityl 29] computer simulations for control strategy development and evaluation 
have used only steady-state collector models. These zero capacitance models do not accurately predict collector performance during short time periods when conditions are rapldy changing. This limitation distorts evaluations of control schemes, particularly when cycling occurs. Also, most studies have evaluated only two or three test cases that are not representative of the span of operating conditions a controller might encounter.

In this study, a dynamic model which includes the effects of collector capacitance is used to evaluate on/off and proportional controllers. Conditions under which each will perform more effectively are determined. Control set points are varied to evaluate their importance and to provide upper and lower bounds for collection efficlency. Flow rates and meteorological conditions are also varied to evaluate the controllers under different situations. Methods for determining the proper control set points are also discussed.

2) DYNAMIC FLAT-PLATE SOLAR COLLECTOR MODEL

The Hotrel-Whilier-Bliss (H.W.B.) collector model $[7,12,16,17,37]$, as adapted by Klein $[19,20]$ to include effects of capacitance, is used to describe the operation of a flat-plate solar collector. The model is based upon a heat balance on a tube and fluid element within a collector, where the entire capacitance of the collector is lumped within the tubes and circulating fluid. The heat balance is solved, using numerical methods on a digital computer, to describe the circulating fluid"s temperature as a function of time and space. 
Klein's major assumptions are:

1. The entire capacitance of the collector, per unit area, including fluld capacitance is represented as a single capacitance coefficient, $C_{A}$.

2. The tube and fluid are at the same temperature.

3. There is no thermal conduction along the tube.

4. The fluid flow is slug flow.

5. The ambient temperature, solar insolatlon, Elow rate, loss factor, and fin efficiency do not vary along the flow direction.

The transient heat balance for a collector element of width $W_{c}$, for flow and no-flow conditions is:

$$
\begin{aligned}
& \partial T_{E, x^{\prime}} \partial t=\gamma\left[\left(F^{\prime} / C_{A}\right)\left[S-U_{L}\left(T_{E, x}-T_{a}\right)\right]-\left(\dot{m}_{p} / C_{A} W_{C}\right)\left(\partial T_{E, x} / \partial x\right)\right] \\
& +(1-\gamma)\left[\left(F^{\prime} / C_{A}\right)\left[S-U_{L}\left(T_{E, x}-T_{a}\right)\right]\right]
\end{aligned}
$$

Where: If $\gamma=1$ pump is running

If $\gamma=0$ pump is not running

and: $\quad W_{C}=$ collector wideh (normal to flow)

$\mathrm{C}_{\mathrm{A}}=$ capacitance coefficient per unit area

$T_{E, x}=$ Eluid temperature at position st

$t=$ time

$F^{\prime}=$ plate fin efficiency factor

$S=$ rate of absorption of incident solar radiation on the collector plate per unit area and is equal to the product of the insolation rate (I) and the transmitrance-absorptance coefficlent (To). 


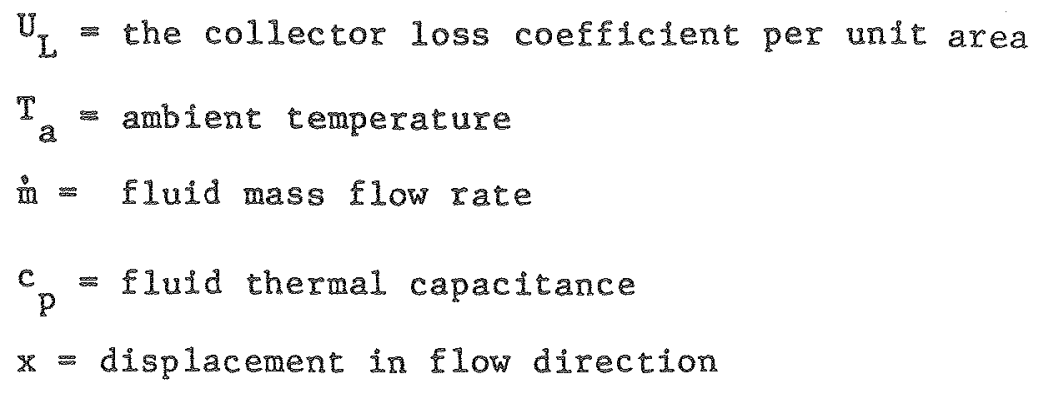

This equation is for a non-drain down collector; fluid stays within the collector even when the pump is off. For a drain down system the collector and fluid capacitance would have to be treated separately.

$\mathrm{C}_{\mathrm{A}}$ is a welghted average of total collector capacitance. Using weighting factors for various collector components Klein[19] has made estimates of $\mathrm{C}_{\mathrm{A}}$ that range from .35 to $.85 \mathrm{BTU} / \mathrm{ft} \mathrm{t}^{2}{ }^{\mathrm{o}} \mathrm{F} \quad(7.2$ to 17.4 $\left.\mathrm{kJ} / \mathrm{m}^{2}-{ }^{\circ} \mathrm{C}\right)$

\section{A Collector Model for Evaluating Control Strategies. Equation 1 is} solved numerically by breaking the collector into a number of nodes or perfectly stirred tanks, thus the time dependent temperature of the $\mathbb{N}^{\text {th }}$ node is written as:

$$
\begin{aligned}
d T_{N} / d t= & \gamma\left[\left(F^{\prime} / C_{A}\right)\left[S-U_{L}\left(T_{E_{N}}-T_{a}\right)\right]+\left(m_{p} / C_{A} W_{C} \Delta x\right)\left(T_{E_{N-1}}-T_{E_{N}}\right)\right] \\
& +(1 .-\gamma)\left[\left(F^{\prime} / C_{A}\right)\left[S-U_{L}\left(T_{E_{N}}-T_{a}\right)\right]\right]
\end{aligned}
$$

For the first node the equation is:

$$
\begin{aligned}
& d T_{I} / d t=\gamma\left[\left(E^{\prime} / C_{A}\right)\left[S-U_{L}\left(T_{E_{1}}-T_{a}\right)\right]+\left(\dot{m}_{p} / C_{A} W_{C} \Delta x\right)\left(T_{i n}-T_{f_{I}}\right)\right] \\
& +(1-\gamma)\left[\left(F^{\prime} / C_{A}\right)\left[S-U_{L}\left(T_{E_{I}}-T_{a}\right)\right]\right]
\end{aligned}
$$

For the last node the equation is: 


$$
\begin{aligned}
\mathrm{dT}_{\text {out }} / \mathrm{dt}= & \gamma\left[\left(\mathrm{F}^{\prime} / \mathrm{C}_{A}\right)\left[S-U_{L}\left(\mathrm{~T}_{\text {out }}-\mathrm{T}_{a}\right)\right]+\left(\mathrm{rC}_{\mathrm{P}} / \mathrm{C}_{A} \mathrm{~W}_{C} \Delta \mathrm{x}\right)\left(\mathrm{T}_{\text {out-1 }}-\mathrm{T}_{\text {out }}\right)\right] \\
& +(1-\gamma)\left[\left(\mathrm{F}^{\prime} / \mathrm{C}_{\mathrm{A}}\right)\left[S-\mathrm{U}_{\mathrm{L}}\left(\mathrm{T}_{\text {out }}-\mathrm{T}_{\mathrm{a}}\right)\right]\right]
\end{aligned}
$$

These equations for $\mathbb{N}$ nodes were solved using the parasol program developed by Auslander[3]. Parasol uses the fourth-order Runge-Rutta method to solve differential equations. The Parasol program s output is the fluid temperature at different posttions along the flow path and for discrete time intervals.

The model described by equations 2,3 , and 4 is adopred for the following reasons:

1) It provides a simple and accurate description of the transient temperature distribution in a collector"s circulating fuid.

2) It included the effects of collector capacitance.

3) It is derived from a well established and respected collector model.

4) Results it provides are usable and consistent with known collector operation.

\section{3) COLLECTOR PARAMETERS}

To compare various control strategies using a computer model, appropriate parameters must be used which represent a typical collector under the influence of common external conditions. Although a multi-node model is used for simulation, a single node model is used to define the appropriate parameters. These parameters are then scaled for use in a multi-node rodel. 
In the limiting case of a single node model equation 2 reduces to [For flow conditions]:

$$
c_{A} d T_{\text {out }} / d t=F^{\prime}\left[S-U_{L}\left(T_{\text {out }}-T_{a}\right)\right]+\left(\dot{m}_{p} / A_{C}\right)\left(T_{\text {in }}-T_{\text {out }}\right)
$$

This equation can also be written to demonstrate the functional dependence of the collector temperature on 1) insolation and ambient remperature, 2) fluid flow rate and 3) collector characteristics:

$$
\mathrm{C}_{\mathrm{A}} \mathrm{d \textrm {T } _ { \text { out } }} / \mathrm{dt}=\left(\mathrm{K}_{\text {gain }}\right) E(t)+\left(\mathrm{K}_{\text {Elow }}\right) \mathrm{T}_{\text {in }}-\left(\mathrm{K}_{\text {Elow }}\right) \mathrm{T}_{\text {out }}
$$

Where: "gain represents the collector"s gain from insolation and losses to the environment

$$
\mathrm{K}_{\text {gain }}=F^{\circ}\left[\mathrm{S}_{\max }+U_{L^{2} \mathrm{~T}_{2, \max }}\right]
$$

$f(t)$ represents the time variation of the normalized

forcing function due to insolation and ambient temperature $\mathrm{K}_{\text {flow }}$ represents the fluid flow rate per unit area of collector

$$
\begin{aligned}
& \mathrm{K}_{\text {flow }}=\dot{\mathrm{m}}_{\mathrm{p}} / \mathrm{A}_{\mathrm{c}} \\
& \mathrm{K}_{\text {flow }}=\dot{\mathrm{m}} \mathrm{c}_{\mathrm{p}} / \mathrm{A}_{\mathrm{c}}+\mathrm{F}^{\circ} \mathrm{U}_{\mathrm{L}} \\
& \mathrm{K}_{\text {flow }} \text { approximately equals } \mathrm{K}^{\circ} \text { flow since } \mathrm{F}^{\circ} \mathrm{U}_{\mathrm{L}} \ll \dot{\mathrm{m}}_{\mathrm{p}} / \mathrm{A}_{\mathrm{c}} \\
& \mathrm{C}_{\mathrm{A}} \text { represents the collector/fluld capacitance per unit area }
\end{aligned}
$$

By allowing $K_{\text {gain }}$ and $K_{\text {flow }}$ (and $\mathrm{K}^{\prime}$ flow ) to take on either HIGH or Low values while keeping all other parameters constant, the control strategy comparisons are based on a limited but comprehensive set of meteorological and flow variations which are used to define limits of operation for a typical collector. The numerical values for the parameters used are described below and summarized in Table 1. 
TABLE I: SUMMARY OF COLLECTOR PARAMETERS AND SIMULATION RUNS

$$
\begin{aligned}
& \text { CAPACITANCE HIGH GAIN HIGH FLOW }
\end{aligned}
$$

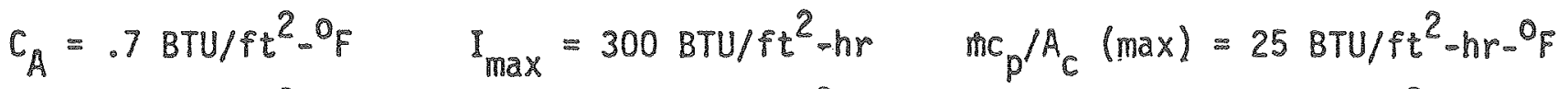

$$
\begin{aligned}
& 14.3 \mathrm{~kJ} / \mathrm{m}^{2}-{ }^{0} \mathrm{C} \quad 946 \text { watts } / \mathrm{m}^{2} \quad 511 \mathrm{~kJ} / \mathrm{m}^{2}-\mathrm{hr}-{ }^{0} \mathrm{C} \\
& T_{a(\max )}=\frac{70^{\circ} \mathrm{F}}{27.7^{\circ} \mathrm{C}} \\
& U_{L}=.7 \mathrm{BTU} / \mathrm{ft}^{2}-h r=\mathrm{F} \\
& 3.97 \text { watts } / \mathrm{m}^{2}={ }^{\circ} \mathrm{C} \\
& T \alpha=0.84 \\
& I_{\max }=150 \mathrm{BTU} / \mathrm{ft} \mathrm{t}^{2}-\mathrm{hr} \\
& 473 \text { watts/m } m^{2} \\
& \begin{array}{r}
T_{a(\max )}=50^{\circ} \mathrm{F} \\
10^{\circ} \mathrm{C}
\end{array} \\
& T_{\text {in }}=115^{\circ} \mathrm{F} \\
& 46.9^{\circ} \mathrm{C} \\
& F^{\prime}=.95 \text { (flow) } \\
& 1.0 \text { (no flow) }
\end{aligned}
$$

\section{LOW FLOW}

\section{SUMPARY OF SIMULATION RUNS}

Clear Day Runs $I=I_{\max }(\sin I t / 172)$

$\begin{array}{ccccc}\text { RUN } & 1 & 2 & 3 & 4 \\ \text { GAIN: } & \text { HIGH } & \text { HIGH } & \text { LOW } & \text { LOW } \\ \text { FLOW: } & \text { HIGH } & \text { LOW } & \text { HIGH } & \text { LOW }\end{array}$

Cloudy Day Runs $I=\left[I_{\max } / 2\right][\sin (\pi t / 12)][\cos (40 \pi t / 12)+1]$

$\begin{array}{lcccc}\text { RUN } & 1 & 2 & 3 & 4 \\ \text { GAIN: } & \text { HIGH } & \text { HIGH } & \text { LOW } & \text { LOW } \\ \text { FLOW: } & \text { HIGH } & \text { LOW } & \text { HIGH } & \text { LOW }\end{array}$


The collector loss coefficient $\left(U_{L}\right)$, the transmittance/ absorptance coefficient $(\tau O)$, and the collector fin efflciency $\left(F^{\circ}\right)$ are kept constant for all simulation runs. Changing them would be equivalent to changing ambient temperature or insolation rate, which is done. The values chosen are typical for well made collectors $[1,2,6,9,12,24,29,35,39,41]$

The dynamics associated with the storage tank and piping to the collector are neglected and therefore the collector inlet temperature, $T_{\text {in }}$ is constant. The value chosen, $115^{\circ} \mathrm{F}\left(46.1^{\circ} \mathrm{C}\right)$, is a representative storage tank temperature [22]. For comparative results, storage tank dynamics are not critical. However, the effect of a 'cold slug' of inlet fluid was examined for a series of simulation runs (see Appendix II).

Preliminary simulation runs showed that changes in collector capacitance, within the range of suggested capacitances, has a minimal effect on comparisons of different control strategies; therefore, collector capacitance, $\mathrm{C}_{\mathrm{A}}$, is kept constant at $0.7 \mathrm{BTU} / \mathrm{ft} \mathrm{t}^{2} \mathrm{O} \mathrm{F}\left(14.3 \mathrm{~kJ} / \mathrm{m}^{2}-\right.$ $\left.{ }^{\circ} \mathrm{C}\right)$. This value was suggested by Klein[20] for a two-cover collector and is compatible with values used in other scudies [9,29].

Collector insolation, heat loss, capacitance and flow rate are all scaled per unit area of collector which allows a majority of the results to be independent of collector area. K Klow is assigned either a HIGH FLOW or LOW FLOW value which represents either an approrimate maximum or minimum value of flow rates used in the solar industry $[2,6,24,28,29,35,39,41]$. These cwo flow rates, 15 and $25 \mathrm{lbm} / \mathrm{ft} \mathrm{t}^{2}-\mathrm{hr}$ $\left(73.2\right.$ and $\left.122 \mathrm{~kg} / \mathrm{m}^{2}-\mathrm{hr}\right)$ provide good comparisons for different collector 
controllers and help define operaring ranges. The circulating fluid is modeled as water with a heat capacity, $c_{p}$, of $1 \mathrm{BTU} / 1 \mathrm{bm}-{ }^{\circ}(4.18 \mathrm{~kJ} / \mathrm{kg}-$ $\left.{ }^{\circ} \mathrm{C}\right)$.

The solar day for all runs is 12 hours long with a peak insolation rate reached at hour 6. For a clear day (no interruptions of insolation) the insolation rate, I, is proportional to a sine wave with a 24 hour period:

$$
I=I_{\max } \sin (\pi t / 12) \quad t=\text { hours }
$$

For a cloudy day the insolation is intermitently interrupted. Follow ing Close[9], the insolation rate as a function of time is:

$$
\left.I=\left(I_{\max } / 2\right)[\sin \pi t / 12)\right][\cos (40 \pi t / 12)+1] \quad t=\text { hours }
$$

The ambient temperature, $T$, is proportional to a sine wave with a 24 hour period, the peak value is at the $g^{\text {th }}$ hour of the solar day:

$$
T_{2}=T 0+T M[\sin (\pi t / 12-\pi / 4)] \quad t=\text { hours }
$$

$k_{\text {gain }}$ 1ike $k_{\text {flow }}$ is assigned either a HIGH GAIN or a LOW GAIN value which represents either a maximum or minimum net energy gain by the collector, independent of the insolation pattern simulated. Peak insolation values are $300 \mathrm{BTU} / \mathrm{Ft}^{2}-\mathrm{hr}\left(946 \mathrm{~W} / \mathrm{m}^{2}\right)$ for the high gain cases and 150 BTU/Et $\mathrm{f}^{2}\left(473 \mathrm{~W} / \mathrm{m}^{2}\right)$ for the low gain cases. These values are applicable for the United States [27] and are consistent with values used in other studies $[15,23,29,31,35]$. Low gain corresponds to low ambient 
$+\quad-10-$

tempexatures and thus maximum collector losses, the opposite is true for high gain cases. The collector temperature is assumed to equal the ambient temperature at sunrise.

4) COLLECTOR FLOW CONTROLLERS

Collection of solar energy is controlled by the flow of fluid through the collector loop (see Figure 1). Collector outlet and storage tank temperatures are compared by a controller to determine the fluid flow rate. The difference between the collector outlet temperature and the storage tank temperature is known as $\Delta \mathrm{T}$ and represents the remperature rise across the collector.

On/Off Control. The on/off controllex is a thermostat which turns the fluid circulation pump either on or off based on the temperature rise across the collector, $\Delta T$. Figure 2 illustrates the operation of the on/off controller and the following definitions apply to this type of controller:

$$
\begin{gathered}
\Delta \mathrm{T}_{\text {off }}=\begin{array}{l}
\text { temperature difference between fluid outlet } \\
\text { and inlet sufficient to turn pump off. }
\end{array} \\
\Delta \mathrm{r}_{\mathrm{on}}=\begin{array}{l}
\text { temperature difference between fluid outlet } \\
\text { and inlet sufficient to turn pump on. }
\end{array}
\end{gathered}
$$

The region between $\Delta T_{\text {on }}$ and $\Delta T_{\text {off }}$ is known as the hysteresis zone. Because of hysteresis on/off controllers have "menory" which limits pump cycling.

Flow rate $(m)$ through the collector can be defined as: 

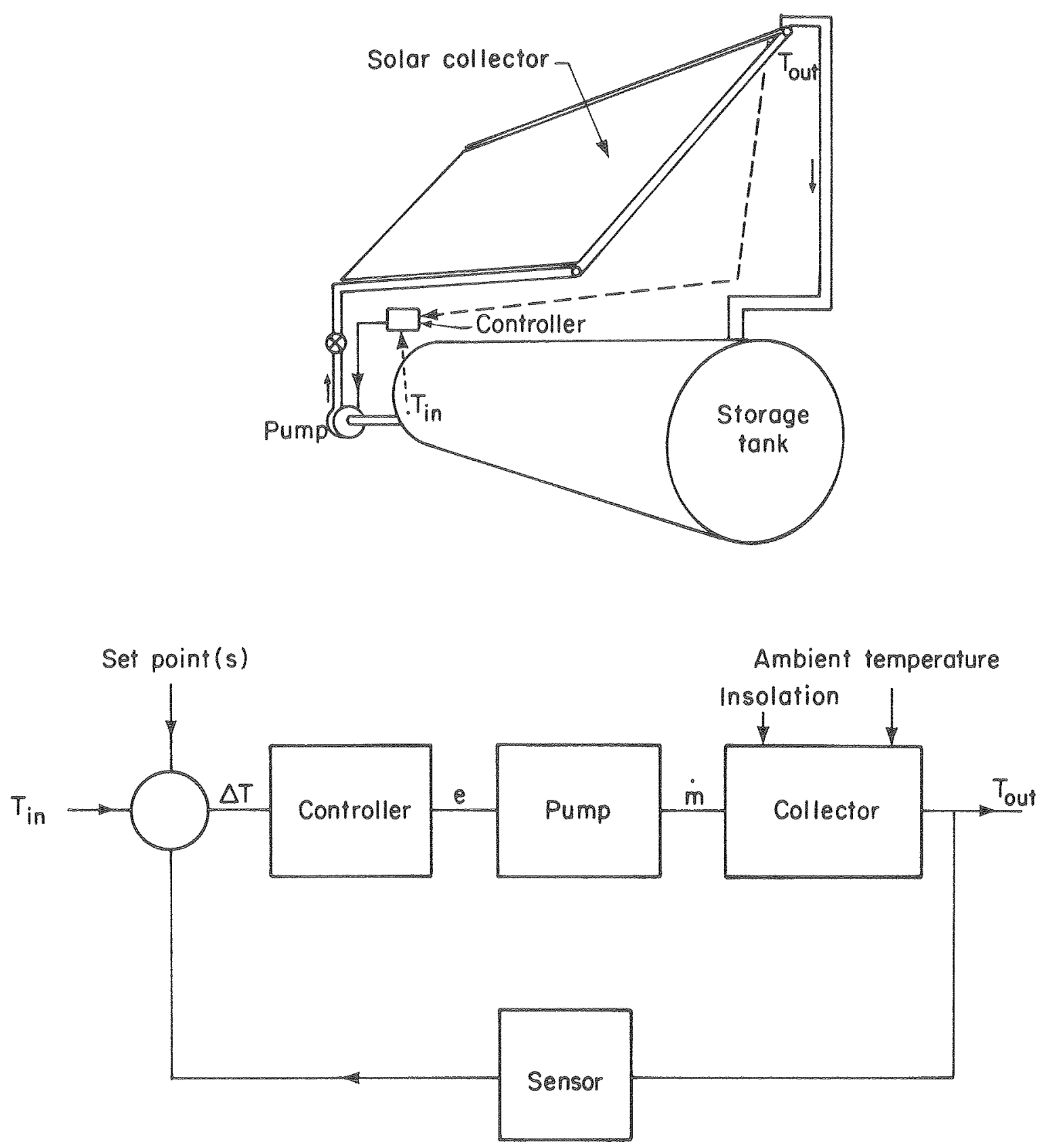

TYPICAL SOLAR ENERGY COLLECTION SYSTEM AND CONTROL BLOCK DIAGRAM 


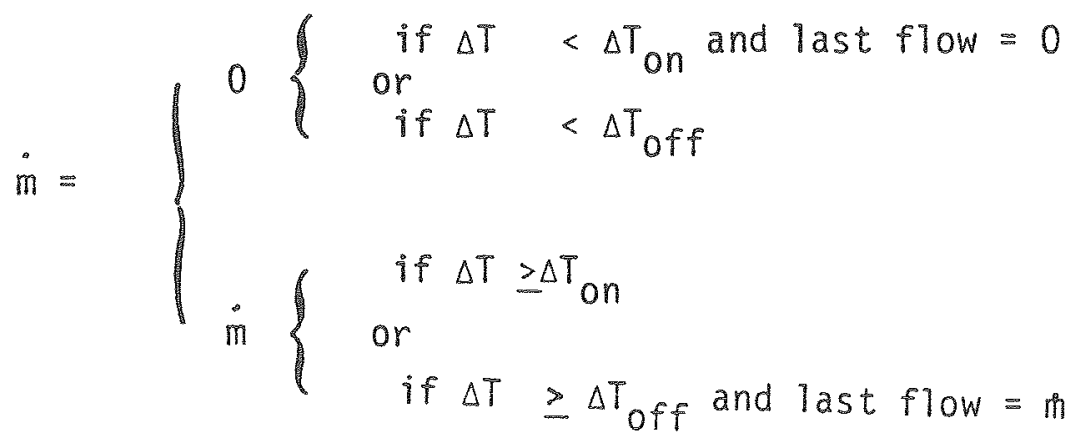

A timer is sometimes added to an on/off controllex to limit pump cycling. The timer delay of 5 - 10 minutes holds the pump on after $4 \mathrm{~T}_{\text {on }}$ has been reached without considering the actual collector temperature. With this type of controller, though, it is possible for the pump to be on when there is a net energy loss from the collector loop.

Proportional Control (with saturation). In this type of Eeedback controller the fluid flow rate is also varied as a function of $\Delta \mathrm{T}$. The advantages of proportionally controlled systems are: fluid circulates at lower values of $\Delta T$ and pump cycling is minimized. Figure 3 shows the characteristics of a proportional controller. The fluid flow rate through the collector is described by the following equations:

$$
m(t)= \begin{cases}0 & \text { for } \Delta T<\Delta T_{\text {off }} \\ k \Delta T & \text { for } \Delta T_{\text {off }} \leq \Delta T \leq \Delta T_{\max } \\ \dot{m}_{c} & \text { for } \Delta T \geq \Delta T_{\max }\end{cases}
$$



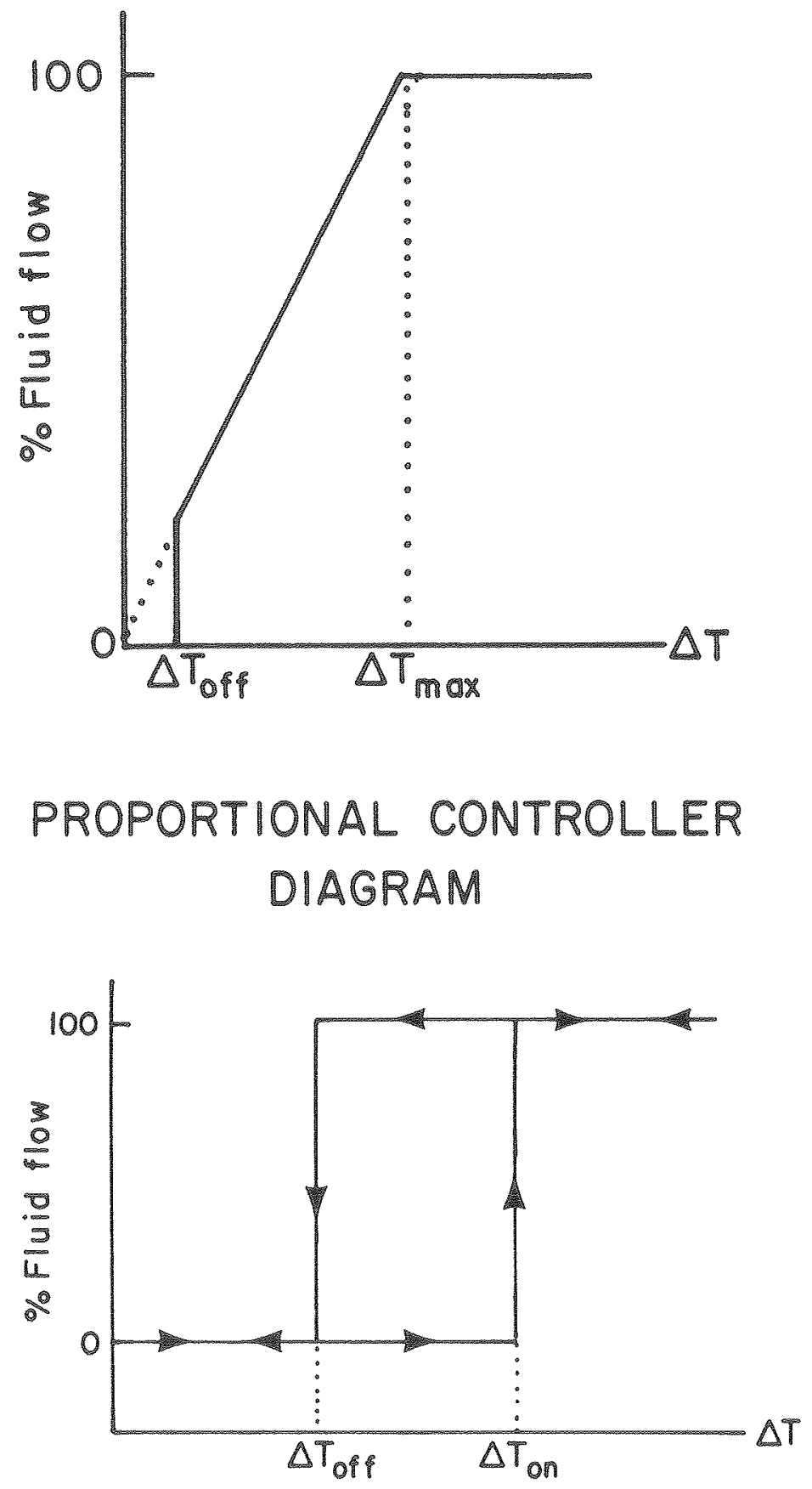

ON/OFF CONTROLLER DIAGRAM

X8L7912-13326A

FIGURES $2 \& 3$ 


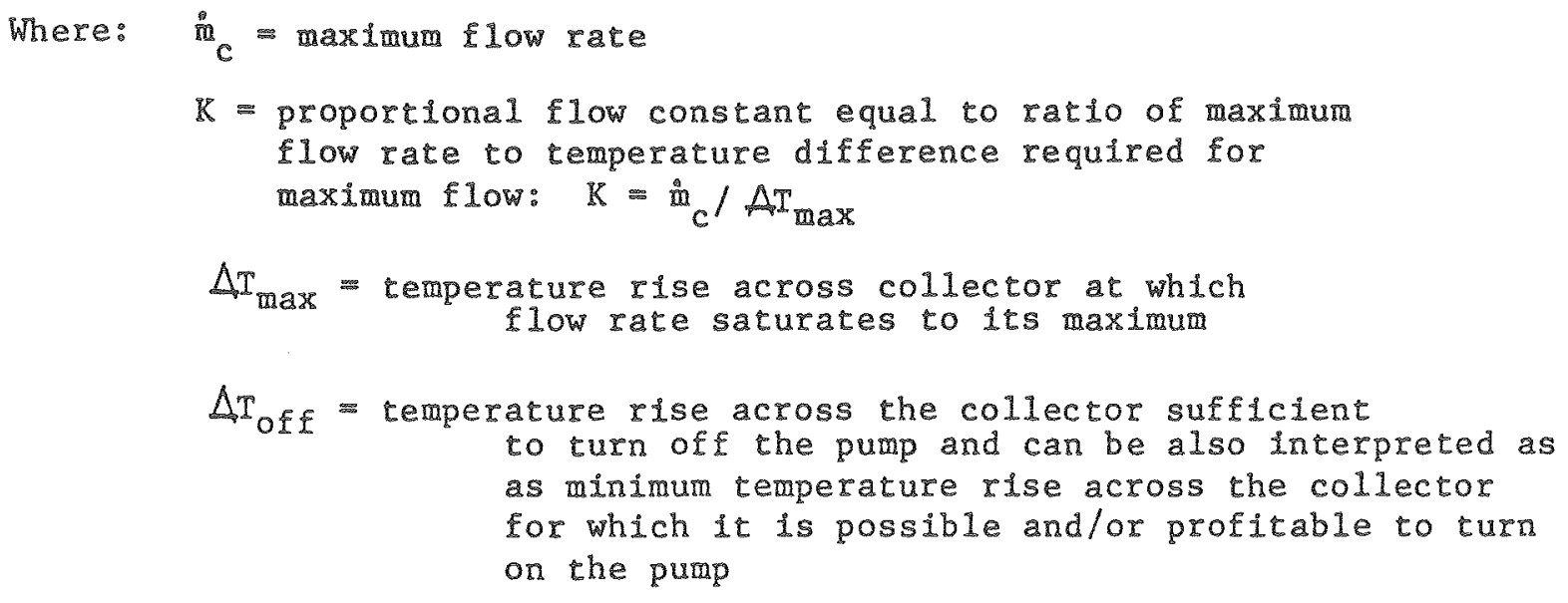

5) DETERHINATTON OF CONTROLLER SET POINTS

In decermining proper controller set points there axe two major considerations: set points must be chosen to maximize energy collection and minimize pumping power(or cost); and set points must be within the capability of the sensors used. The importance of sensor sensitivity and location cannot be overemphasized since these two concerns have caused numerous problems in solat installations $[5,8,25,36]$.

Off Set Point. The minimum temperature rise across the collector, $\Delta T_{\text {off }}$, for which it is useful to turn on the collector loop pump is determined by 1) limitations of a given sensor to differentiate small temperature differences and 2) parasitic power (pumping costs). It has been shown $[21,39]$ that if the collection system does not require parasitic power the ideal set points are: $\Delta T_{\text {off }}$ equal to zero and $\Delta T_{\text {on }}$ equal to some small value above zero. However since pumps do require power it is practical to circulate fluid only when the dollar value of the energy collected is greater than that required to run the pump. The following equalities can therefore be written: 
value of collected power $\geqq$ cost of required pumping power $\frac{\text { (heating power cost })\left(\dot{m c}_{p}\right)\left(\Delta T_{\text {off }}\right)}{\text { (heating system efficiency) }} \geq \frac{\text { (pumping power)(pumping power cost) }}{\text { (pump efficiency) }}$

$\rightarrow \Delta T_{\text {off }} \geq \frac{\text { (pumping power })(\cos t \text { ratio) }}{\text { (efficiency ratio) }\left(\mathrm{mc}_{\mathrm{p}}\right)}$

This equation can be used for both on/off and proportional flow controllers. If a larger value of $\Delta \mathrm{T}_{\text {off }}$ is used, say to meet the sensitivity requirements of an uncalibrated sensor, the pump will cycle more often and less energy will be collected since the pump will shut off sooner than necessary.

For a typical water flow rate of 15 gallons per minute, a one-half horsepower pump motor, an electricity to gas cost ratio of three, and an efficiency ratio of one, $\Delta \mathrm{T}_{\text {off }}$ is only $.51^{\circ} \mathrm{F}\left(.28^{\circ} \mathrm{C}\right)$. This value is much smaller than those typically used and therefore energy collection can be improved using more accurate and sensative cemperature sensors.

On Set Point. Unlike $\Delta T_{\text {off, }}$ only a range of values can be determined for $\Delta T$ on without knowledge of specific weather conditions. To determine an optimum range for $\Delta T_{\text {on }}$ the steady-state $H \cdot W \cdot B$. model is used to analyse the operation of a solar collector. Steady-state collector temperature for no flow conditions is:

$\mathrm{T}_{\mathrm{c}}=\mathrm{S} / \mathrm{U}_{\mathrm{L}}+\mathrm{T}_{\mathrm{a}}$, and for flow conditions is given by;

$T_{\text {out }}=\left[A_{C} E_{R} / \dot{m}_{p}\right]\left[S-U_{L}\left(T_{i n}-T_{\alpha}\right)\right]+T_{\text {in }}$.

Where $F_{R}$ is the collector efficiency factor.

The maximum practical value for $\Delta \mathrm{T}$ on would be one that insures that the pump never cycles. $\Delta \mathrm{T}_{\text {on }}$ is set so that after the pump turns on at 
some level of absorbed insolation, $S_{\text {on }}$, and ambient temperature, $T_{2}(o n)$, the temperature rise across the collector does not fall below $\Delta T_{0}$. Applying this criterion the maximum $\Delta T_{\text {on }}$ can be shown to equal:

$$
\Delta T_{\text {on }}=\frac{\Delta T_{\text {off }}}{F_{R}\left(U_{L} A_{C} / \dot{m}_{P}\right)}
$$

For stable control operation $\Delta \mathrm{T}_{\text {on }}$ should be greater than $\Delta \mathrm{T}_{\text {off }}$. If parasitic power requirements are ignored. $\Delta T_{\text {off }}$ is zero and therefore the minimum value for $\Delta T_{0}$ is also zero. Thus the ratio of $\Delta T_{\text {on }}$ to $\Delta T_{\text {off }}$ should be greater than unity while less than or equal to the ratio of the capacitance flow rate to the approxinate collector heat loss ${ }^{*}$.

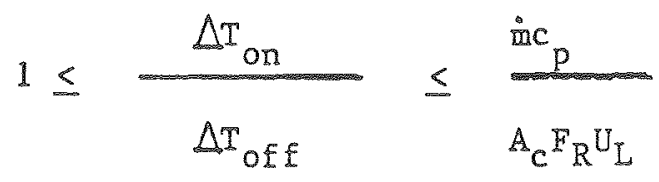

When the following typical values are inserted it is clear that the range of $\Delta \mathrm{T}_{\mathrm{on}} / \Delta \mathrm{T}$ off defined is too conservative.

$$
\begin{aligned}
& \stackrel{\dot{m} c}{\mathrm{p}} / \mathrm{A}_{\mathrm{c}}=20 \mathrm{1bm} / \mathrm{hr}-\tilde{\mathrm{ft}} \mathrm{t}^{2} \\
& U_{L}=0.7 \mathrm{BTU} / \mathrm{ft}^{2}-{ }^{\circ} \mathrm{F} \\
& F_{R}=0.95 \\
& 1 \leq \frac{\Delta T_{\text {on }}}{\Delta T_{\text {off }}} \leq 30
\end{aligned}
$$

[*] Analysis done by Davis [1]] provides a similar result. 
These limits for $\Delta \mathrm{T}_{\text {on }}$ are not very useful since typical ratios used in the solar industry $[5,41]$ are from $2-7$ and they provide satisfactory results while allowing some cycling at low insolation levels.

Proportional Control Set Points. The constants $K, \Delta T_{\max }$ and $\Delta r_{\text {off }}$ are used to determine the fluid flow rate in a proportionally controlled system. $\Delta T_{0}$ ff is the minimum temperature rise across the collector required for stable operation at the mininum flow rate and can be calculated using the method previously outlined.

The constant $K$ is the slope of the control curve and is equal to the ratio of the maximum flow rate to the temperature required for maxImum flow, $\Delta T$ max. The maximum flow rate for a collection system is usually determined by the purp and the pumping resistance.

\footnotetext{
Herczfeld, et. al.[13] determine $\Delta T_{\max }$ and $\Delta T_{\text {off }}$ by maximizing collection efficiency through minimizing collector temperature. This criterion leads to set points which are too small to be measured and a large slope, $\mathbb{K}$, which produces, in effect, bang-bang control. In practice[33] these set points are determined by motor controllability, temperature sensor sensitivity, and operating experience. In general $\mathrm{K}$ is made small enough so that the controller does not lose its sensitivity and act as a bang-bang controller and large enough so that the flow rate reaches its maximum at modest levels of insolarton.
}

6) RESULTS OF CONTROLLER AHD SET POINT COMPARISONS

The controllers are compared on the basis of their performance with 
respect to: collection efficiency, pump runing time and pump cycling. These comparisons are the results of digttal computer simulations of the four-node version of the model previously described with a time step of 0.001 hours for high flow rates and 0.002 hours for low fow rates. The model is implemented on a PDP $11 / 60$ computer.

A total of six controllers were compared under 12 different sets of conditions. The four on/off controllers have the following characteristics:
A) $\Delta \mathrm{T}_{\mathrm{On}}=9^{\circ} \mathrm{F}\left(5^{\circ} \mathrm{C}\right), \quad \Delta \mathrm{T}_{\text {OfF }}=3^{\circ} \mathrm{F}\left(1.7^{\circ} \mathrm{C}\right)$
B) $\quad \Delta_{\mathrm{T}}=21^{\circ} \mathrm{F}\left(11.7^{\circ} \mathrm{C}\right), \quad \Delta \mathrm{T}_{\text {off }}=3^{\circ} \mathrm{F}$
C) $\Delta T_{\text {on }}=9^{\circ} \mathrm{F}$ with a "perfect' timer
D) $\Delta r_{\text {on }}=21^{\circ} \mathrm{F}$ with a 'perfect" timer

The proportional controllers have the following characteristics:
E) full flow at $\Delta T_{C}=9^{\circ} \mathrm{F}=\Delta T_{\text {max }}, \quad \Delta T_{\text {off }}=3^{\circ} \mathrm{F}$
F) full flow at $\Delta T_{C}=21^{\circ} \mathrm{F}=\Delta T_{\max }, \Delta T_{\text {off }}=3^{\circ} \mathrm{F}$

The set points, $\Delta \mathrm{T}_{\mathrm{on}}, \Delta \mathrm{T}_{\mathrm{off}}$ and $\Delta \mathrm{T}_{\text {maxs }}$ were picked to represent upper and lower limits of values used in industry and research $[5,10,13,15,23,28,33,39,41]$.

Timers are used to limit the cycling of a circulating pump; therefore, the "perfect" timer will allow the pump to come on when the $4 \mathrm{~T}_{\mathrm{o}}$ criterion is met and stay on until it is no longer possible to collect energy. This type of controller was modeled for clear day cases only, since its operation is highly dependent on insolation pattern and timer delay. Thus any results from a particular cloudy day could not be geno 
eralized.

Collection effictency $(\eta)$ is used as a non- dimensional indicator of solar energy collection. It is defined as:

$$
n=\frac{\text { energy collected per unit collector area }}{\text { energy incident per unit collector area }} \times 100
$$

Efficiencies attained with the control strategies are compared against each other and a theoretical maximum efficiency. The theoretical maximum efficiency is achieved with a controllex which circulates fluid, at a high rate that causes the collector temperature to equal the inlet temperature, whenever absorbed solar energy is greater than ambient losses. Using the H.W.B. steady-state model the maximum steady-state daily efficiency possible is:

$$
\begin{aligned}
& \sum_{\Delta \tau=0}^{\infty} \int_{\Delta \tau}\left[\frac{\tau \alpha I-U_{L}\left(T_{i n}-T_{a}\right)}{I}\right] d t \\
& \Delta \tau=\text { time segment where } \tau \alpha I>U_{L}\left(T_{\text {in }}-T_{a}\right)
\end{aligned}
$$

One day simulations of different control strategies indicate how their operation varies with set points, timers, meteorological conditions, and flow rates. Table II presents collection efficlencies, pump running times and amount of cycling for different control strategies under assigned conditions. Table III demonstrates the effect of pumping power on collection efficiency and Table IV compares the dynamic and steady-state model evaluations.

Collection Efficlency. For clear day cases collection efficlency 
TABLE II: CONTROLLER STRATEGY COMPARISONS

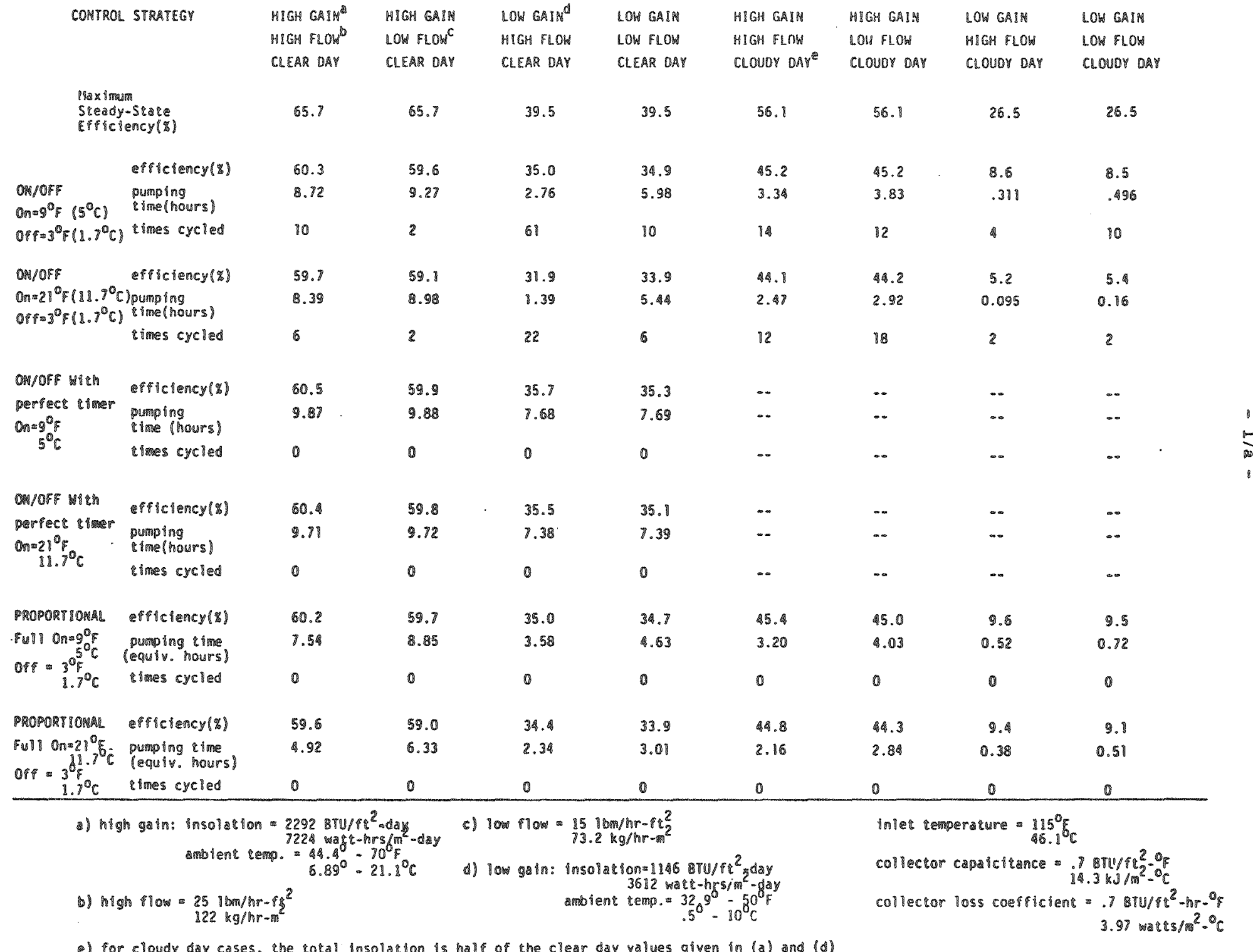


TABLE III: CONTROLLER STRATEGY COMPARISONS INCLUDING PUMPING POWER ${ }^{\mathrm{a}}$

\begin{tabular}{|c|c|c|c|c|c|c|c|}
\hline HIGH GAIN & HIGH & Lord GAIN & LON GAIN & HIGH GAIN & HIGH GAIN & LOW GAIN & LOWH GAIN \\
\hline HIGH FLOW' & LON FLOW & HIGH FLOW & ON & FLOW & FLOW & MIGH FLOW & Son \\
\hline EAP DAY & CLEAR DAY & CUEAR DAY & CLEAR DAY & CLavi Dar & ClOLOY DAY & CLOAOY CAY & 10 \\
\hline
\end{tabular}

CONUROL STRATEGY PUMP SIZE

COLLCUION EFEICIENCIES IN PERGENT

\begin{tabular}{|c|c|c|c|c|c|c|c|c|c|}
\hline $\begin{array}{l}\text { ON/OFF } \\
O=9^{\circ} \mathrm{F}\left(5^{\circ} \mathrm{C}\right) \\
O S F=3^{\circ} \mathrm{F}\left(1.7^{\circ} \mathrm{C}\right)\end{array}$ & $\begin{array}{l}0.1 \mathrm{hp}(7.46 \text { watts) } \\
0.5 \mathrm{mp}(373 \text { watts) }\end{array}$ & $\begin{array}{l}60.1 \\
59.3 \\
\end{array}$ & $\begin{array}{l}59.4 \\
58.6 \\
\end{array}$ & $\begin{array}{l}34.9 \\
39.4 \\
\end{array}$ & $\begin{array}{l}34.6 \\
33.6 \\
\end{array}$ & $\begin{array}{r}45.0 \\
44.5 \\
\end{array}$ & $\begin{array}{r}45.0 \\
40.3 \\
\end{array}$ & $\begin{array}{l}8.5 \\
8.5 \\
\end{array}$ & $\begin{array}{l}8.5 \\
8.3 \\
\end{array}$ \\
\hline $\begin{array}{l}\text { ON/OFF } \\
\text { On=21 } \\
\text { Off } F\left(11.3^{\circ} \mathrm{C}\right)\left(1.7^{\circ} \mathrm{C}\right)\end{array}$ & $\begin{array}{l}0.1 \text { hp }(7.46 \text { wats }) \\
0.5 \text { the }(373 \text { watts })\end{array}$ & $\begin{array}{l}59.5 \\
58.8 \\
\end{array}$ & $\begin{array}{l}58.9 \\
58.1 \\
\end{array}$ & $\begin{array}{r}31.8 \\
31.6 \\
\end{array}$ & $\begin{array}{r}33.6 \\
32.7 \\
\end{array}$ & $\begin{array}{r}4.0 \\
43.6 \\
\end{array}$ & $\begin{array}{r}4.8 \\
43.6 \\
\end{array}$ & $\begin{array}{l}5.2 \\
5.2 \\
\end{array}$ & $\begin{array}{l}5.4 \\
5.3 \\
\end{array}$ \\
\hline 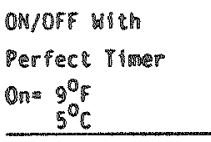 & $\begin{array}{l}0.8 \mathrm{hp} \\
0.5 \mathrm{hp}\end{array}$ & $\begin{array}{l}60.3 \\
59.4\end{array}$ & $\begin{array}{l}54.6 \\
58.8\end{array}$ & 35.4 & $\begin{array}{l}35.0 \\
33.6\end{array}$ & - & - & - & $\stackrel{-}{-}$ \\
\hline 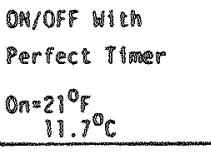 & 0.1 ho & $\begin{array}{l}60.2 \\
59.3\end{array}$ & $\begin{array}{l}59.6 \\
50.7\end{array}$ & $\begin{array}{l}35.2 \\
33.9\end{array}$ & $\begin{array}{l}34.8 \\
33.5\end{array}$ & - & - & - & - \\
\hline 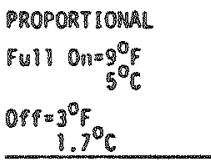 & $\begin{array}{l}0.8 \text { b } \\
0.5 \mathrm{~h}\end{array}$ & $\begin{array}{l}60.0 \\
59.8\end{array}$ & $\begin{array}{l}59.5 \\
58.7\end{array}$ & 34.9 & $\begin{array}{l}34.5 \\
33.8\end{array}$ & $\begin{array}{r}45.3 \\
44.7\end{array}$ & $\begin{array}{l}48.9 \\
44.8\end{array}$ & 9.5 & 9.2 \\
\hline 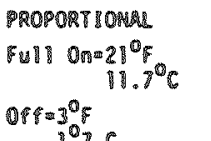 & $\begin{array}{l}0.1 \mathrm{mp} \\
0.5 \mathrm{mp}\end{array}$ & 59.4 & 58.9 & 34.3 & 33.8 & 94.7 & $\$ 4.8$ & 9.4 & 9.0 \\
\hline
\end{tabular}

1) collector efficiency is equal to: (energy collected-pumping fower)/

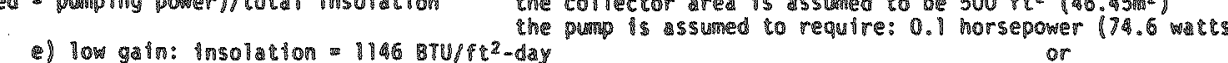

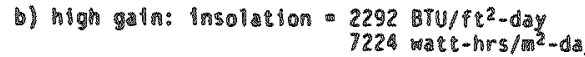

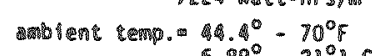

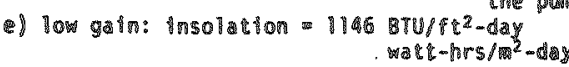
$6.89^{\circ}-21.8 \mathrm{C}$

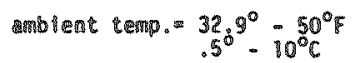

0.5 norsepower (373 wat?s)

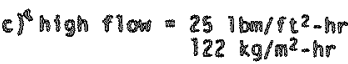

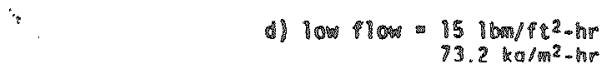
i) For cloudy clay cases, the total Insoldation
is half of the clear day values given in

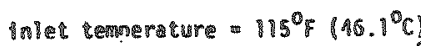

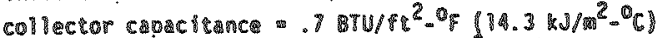

collector loss coeffletens $=.78 r u / 8 t^{2}-3 r-0 F$

$$
\text { (b) and (e) (a) }
$$


for all but one of the controllers is approximately equal and not more than $6.7 \%$ below the maximum steady-state efficiency. on/orf controllers, in general, do slightly better, wh on/off controllexs with timers achieving the best efflelency since they run the pumps for the longest amount of time. For low gain, clear day cases, excesstve cycling of on/off controlled pumps can cause collection efficiency to be less with a high flow rate than with a low flow rate. Normally a higher flow rate leads to higher collection efficiencies; however, when a high flow rate causes excessive cycling the benefits can be outweighed by decreased circulation time.

The off set point, $\Delta T_{\text {off }}$, has a direct effect on energy collection, the higher it is, the less time the pump will run and the lower the amount of energy collected. Therefore, the off set point should be as low as possible while staying within limits of sensor sensitivity and pumping power restrictions discussed previously.

Table II shows that a high on set point, for an on/off controller, can have an adverse effect on energy collection. During days of interrupted insolation or of very low insolation it can take hours longer for the pump to turn on if it does at a11. This problem has been evidenced by collector installations that have very low efficiencles and which do not turn on until late in the day[25].

However, for high gain cases and clear days in general, raising or lowering the onloff controller's $\Delta T_{\text {on }}$ does not greatly affect collecm tion efficiency. For example, it only takes 9.6 minutes longer for the

* When collection efficiencies are compared the criterion is difference between efficiency one and efficiency two $\left(\%_{1}-\%_{2}\right)$. 
higher on set point to be reached in the high gain, clear day cases. For high gain, clear day cases the difference in collection efficiencies for a $\Delta \mathrm{T}_{\mathrm{on}}$ of $21^{\circ} \mathrm{F}$ and a $\Delta \mathrm{T}_{\mathrm{on}}$ of $9^{\circ} \mathrm{F}$ was an average of only $0.5 \%$. For low gain, clear day and high gain, cloudy day cases they differ by an average of about $1.6 \%$.

Relatively small differences in efficiencies between different set points can be explained by the fact that solar collectors act as storage devices. When fluid is not circulating, collectors heat up towards their stagnation temperature and store energy. This energy, equal to the product of the collector"s "effective" capacitance and the difference between stagnation and operating temperatures, is released into the Eluid once it begins to circulate through the collector. This result has been suggested by Herczfeld, et.al.[14], Pejsa[31] and, Orbach, et. a1. [29].

Effects of collector capacitance are important and cannot be considered in steady-state analysis. Steady-state analyses tend to exaggerate the importance of cycling, ignore the effects of the turn on set point and cannot consider cumulative solar input. Thus the predicted amount of heat transferred to the fluid duxing initial circulation will be less than the dynamic model's prediction. These problems are demonstrated in Table IV where the H.W.B. steady-state model and the dynamic model often give very different predictions for collection efficiencies.

While proportional controllers have the advantage of circulating fluid when only a small cemperature rise across the collector is experienced, proportional control will maintain lower average flow rates than on/off control; allowing higher collector temperatures and increased 
heat losses to the environment. While decteasing collection efficiency this may improve storage scratification and overall system efficiency.

Proportional controllers always perform becter with a higher max Imum flow rate. Generally, the larger the proportionality constant, $\mathbb{K}_{\text {, }}$

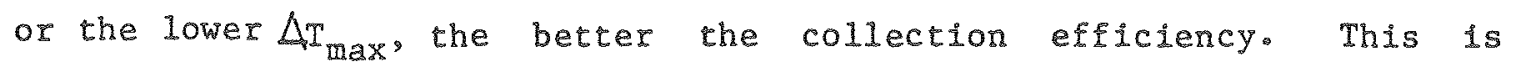
because the maximum flow rate becomes easier to obtain and collector operating temperatures are lower.

In all high gain cases, clear and cloudy days, along with low gain, clear day cases the advantage the proportional controller has by turning on early is eliminated by lower average flow races. For these cases collection efficiencies are within the range for on/off controllers with the same set points. Only for low gain, interrupted insolation cases do proportional controllers show a clear advantage over on/off controllers. Under these conditions, proportionally controlled systems were able to collect a higher percentage of the maximum steady-state efficiency of $26.5 \%$. Neither type of controllex though, is able to achieve erficiencies close to maximum steady-state efficiency; thus, improved controller design nay be appropriate for climates where this type of weather pattern is predominant.

Pumping Time. In table II the amount of time a pump is on, pumping time, is shown. Parasitic energy usage is equal to the product of aver age pump power required and pumping time. Pumping time for an on/off controller is simply the amount of time that fluid is circulating. For proportional controllers an equivalent pumping time is calculated, since the pump is not always producing full flow. For this study equivalent 
pumping time is defined as:

$$
\sum_{\Delta \tau=0}^{\infty} \int_{\Delta \tau}\left[\frac{\text { Flow Rate }(s)}{\text { Maximum Flow Rate }}\right] d t
$$

Where $\Delta t=$ time segment where pump is on

Net efficiency which includes parasitic or pumping power is defined as:

$$
n_{p}=\frac{\text { total energy collected less pumping energy required }}{\text { total energy incident on the collector }(s)} \times 100
$$

In Table III, the effects of pumping time on collection efficiency are shown to be negligible for a typical collector array of 500 $\mathrm{Et}^{2}\left(46.5 \mathrm{~m}^{2}\right)$ with 0.1 horsepower(74.6 watt) pump. In all cases, inclusion of pumping power does not change the ranking of any controller with respect to another; however, if a 0.5 horsepower ( 373 watt) pump is considered the effect of parasitic power makes a very slight change in rankings. For example, on/off controllers with 'perfect' timers are no longer always the most efficient, since they run the pumps for an extended period of time.

Pump Cycling. Since pump cycling is considered a problem with on/off controllexs $[5,14,23,25,35,41]$ the number of times a collector pump cycles during one day has been indicated in Table II. Figure 4 shows a typical cycling sequence as predicted by the computer model. As expected pump cycling decreases with the use of higher on set points, lower off set points or proportional controllers. If cycling is minimal, collection efficiency will not be affected significanty since 


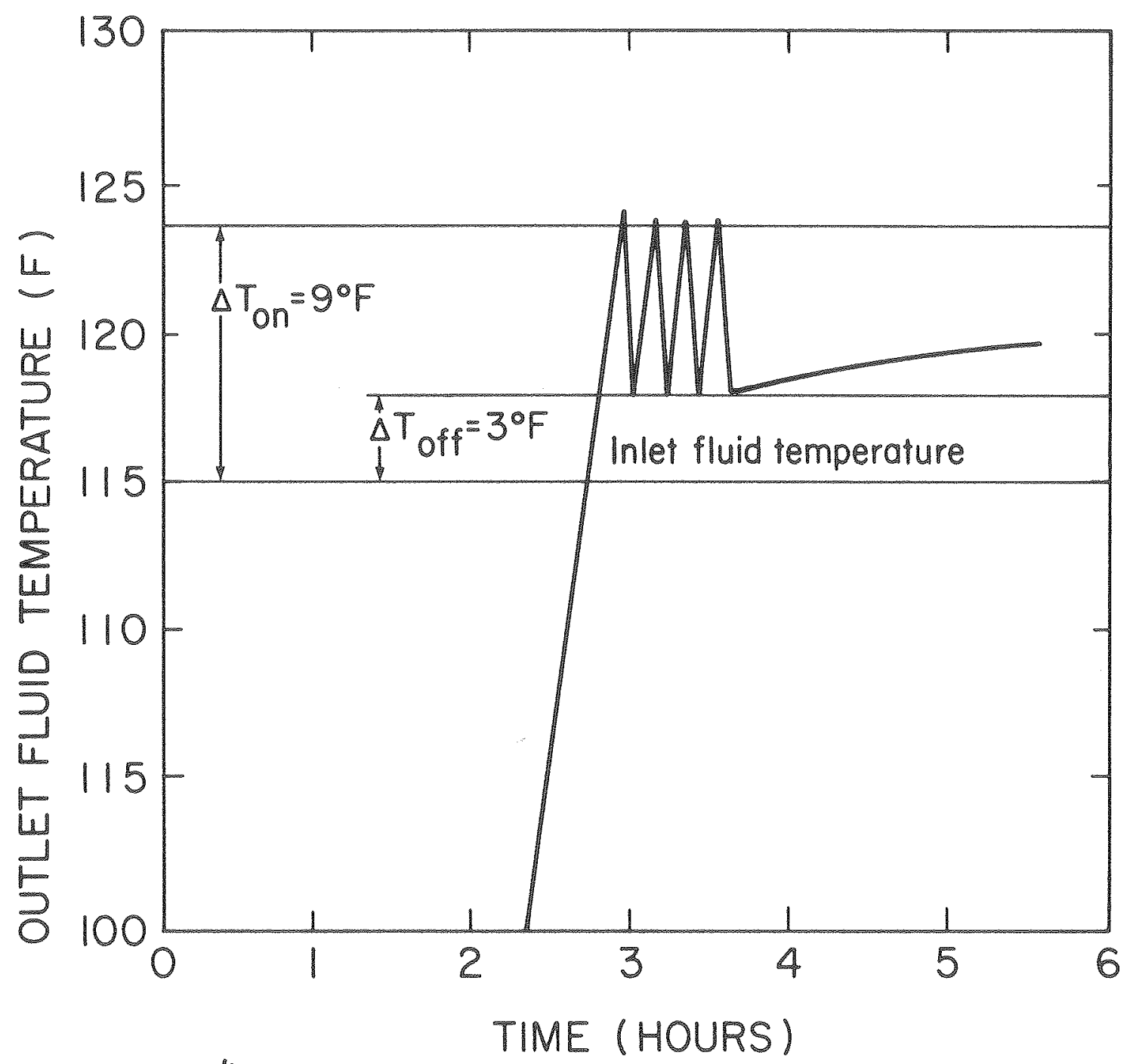

FIGURE 4:

OUTLET FLUID TEMPERATURE

LOW GAIN, LOW FLOW, CLEAR DAY 
1) cycling will occur over a short increment of the total collection time and,

2) the collector wil store energy when fluid is not circulating.

\section{7) CONCLUSTONS}

In this study, a dynamic solar collector model is used to determine the characteristics and relative merits of proportional and on/off collector loop flow rate controllers. The importance and detemination of controller set points are a1so discussed.

On/off and proportional controllers both have collection efficiencies which are close to the maximum possible during days of cleax skies or very high insolation levels. It is doubtful that any other type of controller could do bettex under similar conditions. During periods of interrupted insolation neither proportional nor on/off controllers respond well to rapid changes in insolation rate and collection efficiency falls well below the maximum possible. often this is because a significant portion of the energy incident on the collector can be collected only at collector temperatures less than those required for flow by the controllexs. This indicates that improved temperature sensors, which allow smaller values of $\Delta T_{\text {off }}$ to be implemented, can improve collection efficiency.

However, proportionally-controlled collectors can collect more energy during periods of interrupted and very low insolation levels than on/off controlled systems. This is because proportional controllers are more sensative to changes in insolation and ambient temperatue than on/off controllexs. This advantage of proportional controllers is minimized by the use of a relatively $10 \mathrm{~W} \Delta \mathrm{T}$ on valve $\left(9^{\circ} \mathrm{F}\right)$.

The on/off controller's on set point can have a minimal effect on energy collection as long as it is not so high that the circulator pump does not come on until late in the morning. This is because the collector's capacitance stores energy when the fluid is not clrculating. 
Because the collector acts as a storage device low to moderate cycling of the pump motor also has a minimal effect on energy collectlon.

If the proportional controller's set point for maximum fow is too high, the flow rate will never reach maximum and ambient losses are increased. However, if it is too low, the proportional controller's sensitivity will be lost and the controllex will act as a bang-bang controller.

The off set point for on/off and proportional control has simple criteria: energy collection rate exceed parasitic pumping power and the point selected meet sensor exror requirements. On set points, however, do not have simple criteria and can be defined only within a broad range.

Implications for the design and evaluation of proportional and on/off control are twofold. First, the difference between a steadystate and a dynamic analysis of control strategies is significant. Future work in modeling control systems must consider collector capacitance in order to describe accurately the transient response of fluid temperature. Second, neither on/ of nor proportional control performs best for all conditions. Whether on/off or proportional control should be implemented is dependent on the weather conditions in the location being considered. It is hoped that the results of this analysis will he useful as a guideline to indicate meteorological and flow rate conditions for which on/off or proportional control are more advantageous.

Further work in comparing control strategies and controllers should 
Include: 1) additonal simulation studies using this or an lmproved dynamic solar system model which includes load loop dynamics, 2) experimental testing of control strategies on factlities which can duplicate meteorological and load conditions for comparisons and 3) fleld tests. Experimental testing is now under way at Lawrence Berkeley Laboratory by the authors. 
8) SOURCES CONSULTED

1. Anderson, B. Solar Energy, Fundamentals in Building Design。 (NY: MCGraw-H111 Book Company, 1977)

2. Arafa, Ao, Fisch, No and Mahne, E. "A Parametric Investigation On Flat-Plate Solar Collectors." Proceedings of 1978 ISES Meeting (New Deihi, India): 917-923.

3. Auslander, D.M. "A Continuous System Simulation Language Designed For LSI Economics" Mathematics and Computers in Sirulation, Vol. 20 $(1978): 308-313$.

4. Auslander, D.Mo, Tomizuka, $M$. and Lee, H. "An Optimal Standard

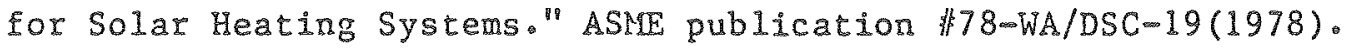

5. Bartlett, J.C. "Evaluation of Solar Energy Control Systems." Proceedings of the Solar Heating and Cooling Operational Results (Colorado Springs, Co: November, 1978): 419-423.

6. Beckman, W.A., Klein, S.A. and Duffie, J.A. Solar Heating Design By The F-Chart Method. (NY: Wiley-Interscience Publications, 1977): Chap. 2.

7. Bliss, R.W. "The Derivation of Several "Plate-Efficiency Factors" Useful in the Design of Flat-Plate Solar Heat Collectors" Solar Energy Vol. 3, No. 4 (1959): 55-64.

8. Cash, M. "Learning From Experience." Solar Age (Nov, 1978): 14-15 
9. Close, D.J. "A Design Approach For Solar Processes." Solar Energy Vo1. 11, No. 2 (1967): 112-122

10. Conway, T. "Fluid Flow Control Strategies in Flat-Plate and Evacuated Tube Collectors." Proceedings of 1977 ISES Meeting (Orlando, FL): $9.11-9.14$.

11. Davis, E.S. "Stabllity of Differential Thermostats For Solar Collector Systens" inter-office meno., C.I.T. Jet Propulsion Laboratory (January, 1975).

12. Duffie, J.A. and Beckman, WoA. Solar Energy Thermal Processes. (NY: Wiley-Interscience Publications, 1974): Chap. $\%$

13. Herczfeld, P.R., Fischl, R. and Orbach, A. "Optimizing Solar Energy Systems Using Continuous Flow Control." Proceedings of 1978 ISES Meeting(New Delhi, India): 1523-1430.

14. Herczfeld, P.R., et.al. "Study of Pump Cycling in the Control of Solar Heating and Cooling Systems." Proceedings of the Workshop on the Control of Solar Energy Systems for Heating and Cooling of Buildings(Hyannis, MA: May, 1978), U.S. Department of Energy.

15. Honeywe11 Energy Resources Center. "Cost-Effective Control Systems for Solar Heating and Cooling Applications, Final Report." (September, 1978)

16. Hotrel, H.C. and Whillier, A. "Evaluation of Flat-Plate Solar Collector Performance "Transactions of the Conference on the 
Use of Solar Energy, Vol. II, Thermal Processes (University of Axizona, 1955): $74=104$.

17. Hotte1, H. C. and Woert, B.B. "Performance of Flat-Plate Solar Heat Collectors" Transactions of the ASME, 64 (1942): 1942 .

18. Kays, W.M. and London, A.K. Compact Heat Exchangers. (NY: MeGraw-Hill Book Co., 1964): Chap. 3.

19. Klein, S.A. "The Effects of Thermal Capacitance Upon the Performance of Flat-Plate Solar Collectors." M.S. Thesis, University of Wisconsin, 1973.

20. Klein, S.A., Duffie, J.A. and Beckman, W.A. "Transient Considerations of Flat-Plate Solar Collectors."ASME Journal of Engineering Power, 96 A (1974).

21. Kovarik, H. and Lesse, P.F. "Optimal Control of Flow in Low Temperature Solar Heat Collectors." Solar Energy Vol. 18, no. 6 (1976)。

22. Lee, C., Tay1or, L., DeVries, Jo and Hellbein, S. "Solar Applications of Thermal Energy Storage." Proceedings of the Solax Energy Storage Options Workshop (San Antonio, TX: larch, 1979). Argonne National Laboratory.

23. Lewis, R. and Carr, J. "Comparative Study on ON/OFF and Proportionally Controlled Systems." Proceedings of the Workshop on the Control of Solar Energy Systems for Heating and Cooling of Buildings. (Hyannis, MA: May, 1978). U.S. Department of Energy. 
24. Los Alamos Scientifle Laboratory, Solar Energy Group. "BRDA Pacific Reglonal Solar Heating Handbook" (Los Alamos, NM: November, 1976). $2^{\text {nd }}$ edition.

25. McCumber, W. IBM Corporation, Federal Systens Division, Huntsville, Alabama. private communication, April, 1979.

26. McDonald, T, Farris, D. and Melsa, Jo "Energy Conservation Through Adaptive Optimal Control For a Solar Heated and Cooled Building." Proceedings of the Workshop on the Control of Solar Energy Systens For Heating and Cooling of Buildings (Hyannis, MA: May, 1978), U.S. Department of Energy.

27. Morrison, C.A. and Farber, E.A. "'Development and Use of Solar Insolation Data in Northern Latitudes For South Facing Surfaces." Proceedings of the ASHRAE Annual Meeting, Volume 80 , part 2 (Montreal, Quebec: June, 1974): 352-363.

28. Orbach, A., et.al. "Flow Control in Solar Heating and Cooling Applications." Proceedings of 1978 ISES neeting, (New Delhi, India): $488-492$.

29. Orbach, A., et.al. "Optimal and Sub-Optimal Control Strategies and Sensitivity Study for Solar Liquid Collector Systems." Proceedings of 1979 ISES Annual Meeting (Atlanta, GA: May, 1979).

30. Pacific Gas and Electric Company Domestic Rate Schedules for Gas and Electricity: electric: April 1, 1978; gas: September 11, 1978.

31. Pejsa, J.H. Honeywell Corp. Energy Resources Center, Minneapolis, 
MN. privace communication, October, 1978.

32. Sager, J.Co, Goldberg, B. and Klein, W.H. Wlat-Plate Collector Dynamic Evaluation." Proceedings of the 1978 ISES Meeting (New Delhi, India).

33. Schlesinger, R.J. "Operating Cycle For A Typlcal Solar Heating System." Solar Engineering Feb./Rarch (1976): 26-28.

35. Schlesinger, R.J. "Preliminary Comparison of Proportional and Fu11 On-Off Control Systems for Solar Energy Applications." Proceedings of the 1977 ISES meeting (Or lando, FL): 9.15-9.18.

34. Schlesinger, R.J. President, Rho Sigma Co., Van Nuys, CA. private comunication, May, 1979.

36. Sparkes, H.R. and Raman, K. "Lessons Learned on Solar Systen Design Problems From the HUD Solar Residential Demonstration Program." Proceedings of the Solar Heating and Operational Results Meeting (Colorado Springs: November, 1978): 25l-256.

37. Whilliex, A. "Solar Energy Collection, and Its Use For House Heating" Sc. D. Thesis, M.I.T., 1959.

38. Winn, B.C. "Optimal Control of Active Solar Systens." Proceedings of the Workshop on the Control of Solar Energy Systems for Heating and Cooling of Buildings (Hyannis, MA: May, 1978). U.S. Department of Energy.

39. Winn, B.C. and Hu11, D. "Optimal Controllers of the Second Kind." Proceedings of 1978 ISES meeting (New DeIhi, Inda): $493-498$. 
40. Yusoff, M. and Close, D.J. "Transient and Steady-State Considerations of Solar Air Meaters." Proceedings of 1978 ISES Meeting (New DeIhi, India).

41. Manufacturer's Product Bulletins from the following companies:

Andover Controls. B.0. Box 34 SUS, Andover, MA

Grundfos Pumps Corp. 2555 Clovis Ave, Clovis, CA

Helitrope General. 3733 Kenora Dr., Spring Valley, CA

Honeywell Energy Center. 2700 Ridgeway, Minneapolis, MP

Independent Energy. P.0. Bos 732, E. Greenwich, RI

Johnson Controls Inc. Penn Division, 2221 Camden, Dakbrook, IL

March Manufacturing Inc, P.0. Box 87, 1819 Pickwick, Glenview, IL

Natural Power, Inc. New Boston, NH

Piper Hydro Inc. 3031 E. Coronado, Anaheim, CA

PPG Industries Glass Division. One Gateway Center, Pittsburg, PA

Rho Sigma Inc. 15150 Raymer St, Van Nuys, CA

Solar Control Corp. 5595 Arapahoe Rd,, Boulder, Co 
NOMENCLATURE

A Collector plate suxtace area

$C_{A}$ Effective value of collector capacitance, per unit collector area

$c_{p}$ Thermal capacitance of circulating Eluid

$F^{\text {Plate }}$ in efficiency factox

$F_{R}$ Collector eficiency factor

R Proportionality constant for proportional controllexs

$K_{\text {flow }}$ Represents the fluid flow rate per unit area

Kgain Represents the collector"s gain from insolation and losses to the envinonment, per unit area

I Solar insolation rate, per unit area

m Fluid mass flow rate

N Number of segments (ox stirred tanks) that collector is divided up into

S Rate of absorption of solar insolation by collector plate, per unit area

$t \quad$ Time

Ta Ambient temperature

TM Ambient cemperature calculation constant

To Ambient temperature calculation constant

$T_{E_{8}}$ Fluid temperature at position $x$

$T_{\text {in }}$ Inlet Eluid temperature

Tout outlet fluid temperature

U collector loss coefficient, per unit area

W Width of collector in the dixection to klow

* Displacement in flow direction 


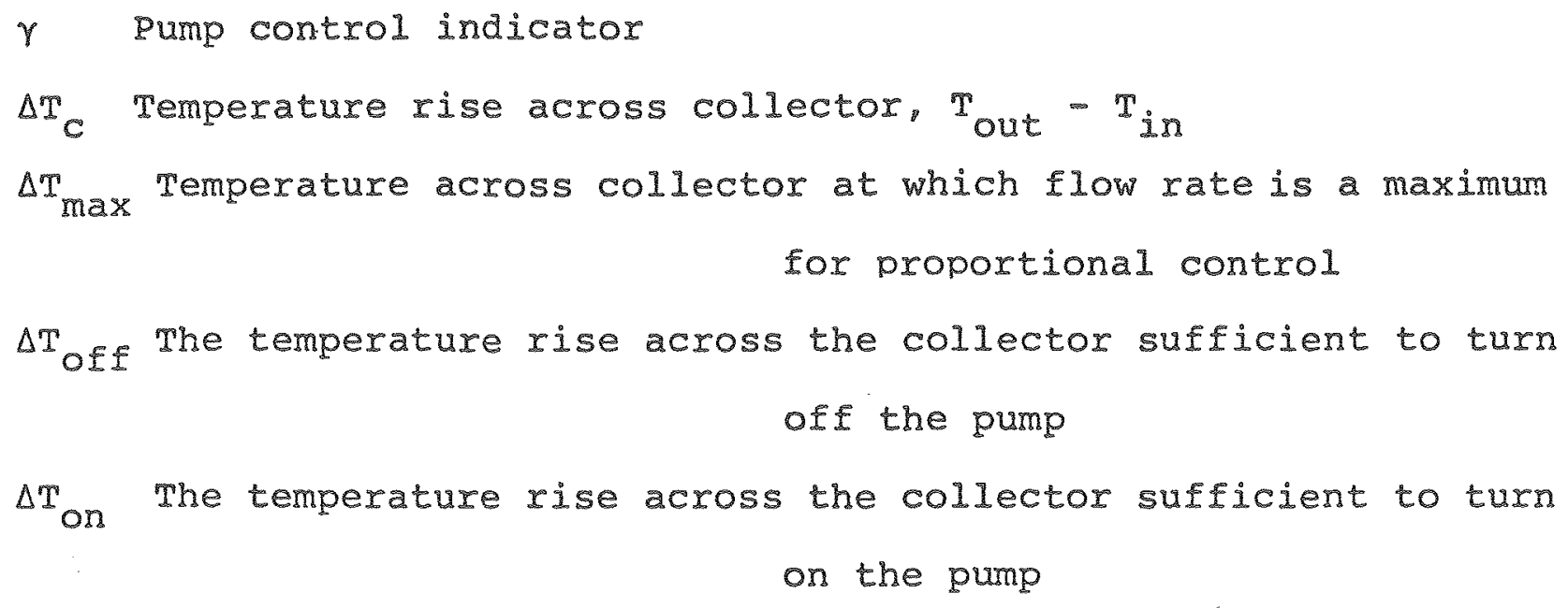

n collector efficiency

$\eta_{\mathrm{p}}$ Collector efficiency including pumping power

ta Transmittance/Absorptance coeficient 
APPENDIX I Additional Figures

Figure 5 shows the tube and fludd element on which the collector model ${ }^{\circ} \mathrm{s}$ heat balance $1 \mathrm{~s}$ performed. Figures 6,7 and 8 indicate the insolation patterns for a clear day and a cloudy day, and the outdoor temperature profiles used, respectively.

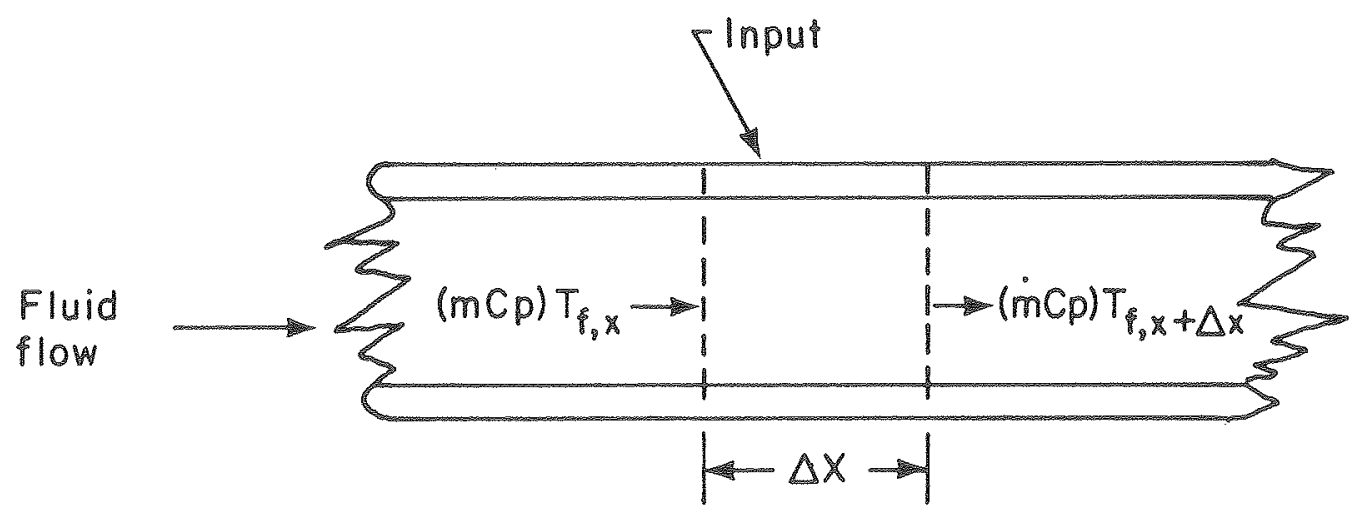

FIG. 5: COLLECTOR TUBE/FLUID ELEMENT

XBL $7912-13327$ 


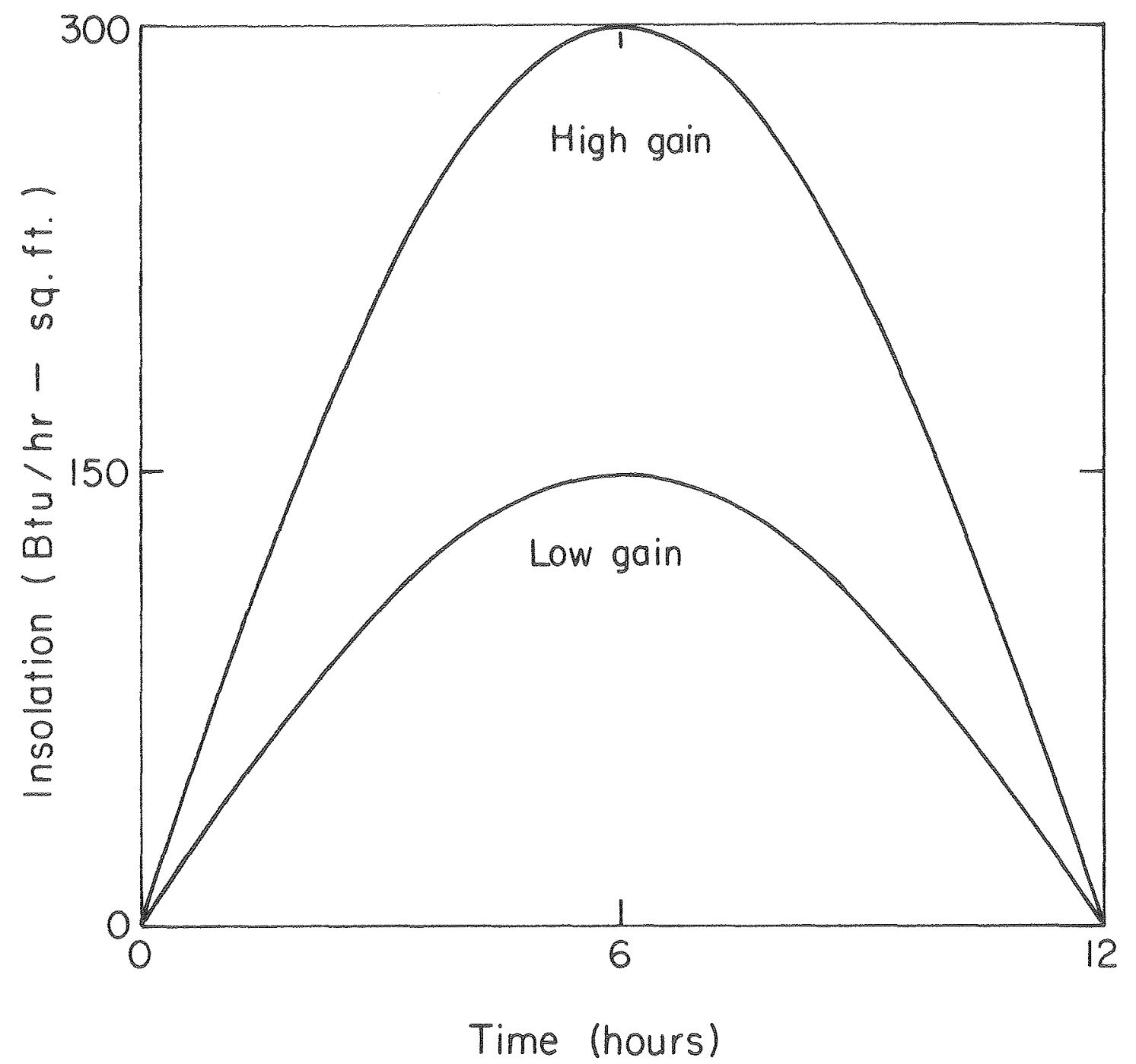

FIG. 6: INSOLATION ON A CLEAR DAY HIGH AND LOW GAIN 


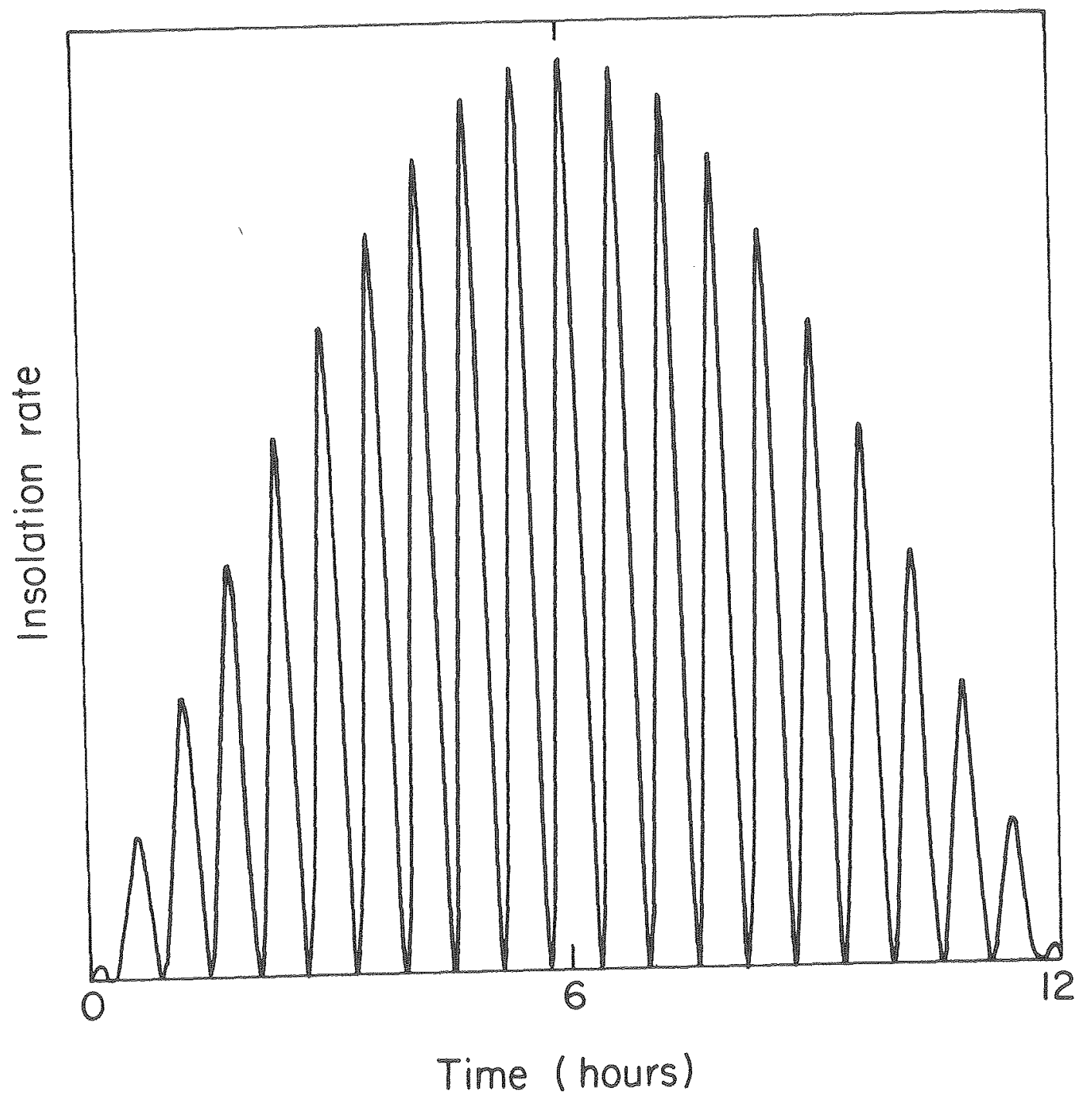

FIG. 7: SOLAR INSOLATION ON A CLOUDY DAY

$$
x B L 7912-13324
$$




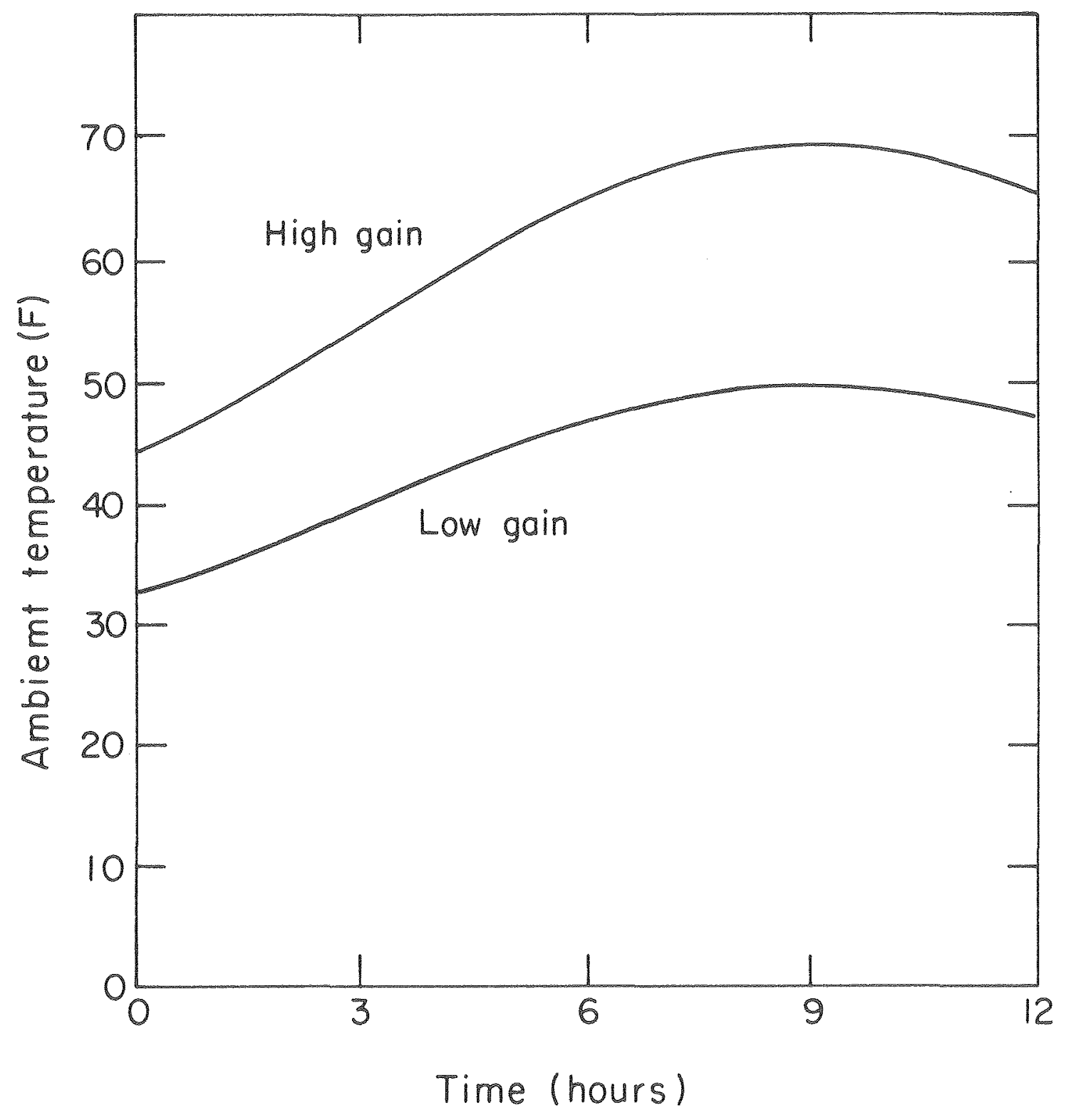

FIG. 8: AMBIENT TEMPERATURE HIGH AND LOW GAIN 
APPENDIX II Simulation Runs Whth A Cold Slug Input

Table $V$ shows collector efflciencles for different strategles with the additional condition that a cold slug of fluld enters the collector for a set period of time. The cold slug of fluld is a phenomenon experienced by many collectors when the fluid is first circulated. In a non-drain down collector system fluld is left in the collector inlet pipes, which lead from the storage tank to the collector, at the end of each solar day. Fluid in these pipes can reach ambient temperature by the start of the next day. However, the inlet sensor, which is located in the storage tank, does not indicate the inlet pipe fluid temperature.

Therefore, at the beginning of a new solar day, the controller will send fluid into the collector which it believes is at the storage temperature but is actually at or close to ambient. This will continue until the "cold slug' has gone through the entire length of exposed inlet piping. This condition can obviously confuse a controller, which is the main reason for considering it in the comparisons.

For the cold slug cases, the inlet fluid is at the ambient temperature, and not the storage tank temperature, for the length of time required for a slug of fluld to transverse a 100 foot 1ong, $1 / 2$ inch diameter pipe. For the on/off controllers, which maintain a constant flow rate, it would take 72 seconds with the high flow rate and 119 seconds for the low flow rate. These times are appropriately adjusted for the proportional flow controllers. The cold slug is only modeled during clear days because its effect, 11ke that of the timer, is dependent on insolation patterns; therefore, results can not be generalized. 
With the input of a cold slug during the early morning the relative advantages of on/off and proportional controllers are unchanged from the cases without the cold slug (see Table II). 


\section{TABLE $V_{i}$ CONTROLLER STRATEGY COMPARISONS}

\section{FOR COLD SLUG AT INLET 6 HOUR TOTALS}

CONTROL STRATEGY

ON/OFF

on $=9^{\circ}$

off $=3^{\circ} \mathrm{F}$ $1.7^{\circ} \mathrm{C}$

efficiency $(\%)$

55.1

3.96

(hours)

ON/OFF

$\begin{array}{rr}\text { On }=21^{\circ} \mathrm{F} & \text { efficiency(\%) } \\ 11.7^{\circ} \mathrm{C} & \\ \text { off }=3^{\circ} \mathrm{F} & \text { pumping time } \\ 1.7^{\circ} \mathrm{C} & \text { (hours) }\end{array}$

PROPORTIONAL

Full on $=9_{5^{\circ} \mathrm{C}}^{\circ}$ efficiency $(\%)$

off $=3^{\circ} \mathrm{F} \quad \begin{aligned} & \text { pumping time } \\ & 1.7^{\circ} \mathrm{C}\end{aligned} \quad$ (equiv. hours)

54.9

54.3

27.2

26.8

3.34

PROPORTIONAL

Full on $=21^{\circ} \mathrm{F}$ efficiency $(\%)$

54.2

53.5

26.5

2.8

2.18

3.9

1.32

1.71 off $=3^{\sigma_{F}} \quad \begin{aligned} & \text { pumping time } \\ & 1.7^{\circ} \mathrm{C}\end{aligned}$

a) high gain: insolation $=2292 \mathrm{BTU} / \mathrm{ft}^{2}-$ day 7224 watt-hrs/m $-d a y$

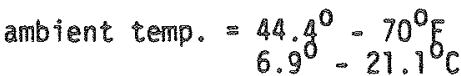

d) Iow gain: insolation $=1146 \mathrm{BrU} / \mathrm{ft} \mathrm{t}^{2}$-day 3612 watt-hrs/m $/ \mathrm{m}^{2}$-day ambient temp. $=329^{\circ}-50^{\circ} \mathrm{F}$

c) Iow flow $=15 \mathrm{lbm} / \mathrm{ft}^{2}-h \mathrm{r}$ $73.2 \mathrm{~kg} / \mathrm{m}^{2}-\mathrm{hr}$ cold slug duration: 119 seconds

cold slug duration: 72 seconds

$$
\begin{aligned}
& 251 \mathrm{bm} / \mathrm{ft}^{2}-\mathrm{hr} \\
& 122 \mathrm{~kg} / \mathrm{m}^{2}-\mathrm{hr}
\end{aligned}
$$

cold slug temperature ambient temperature collector inlet temperature $=115^{\circ} \mathrm{F}\left(46.1^{\circ} \mathrm{C}\right)$ collector capacitanca $=0.7 \mathrm{gTU} / \mathrm{ft}^{2}-0 \mathrm{~F}\left(14.3 \mathrm{~kJ} / \mathrm{m}^{2}-{ }^{\circ} \mathrm{C}\right)$ collector loss coeffictent $=0.7 \mathrm{BTU} / \mathrm{ft}^{2}-\mathrm{hr}-{ }^{\circ} \mathrm{F}\left(3.97\right.$ watts $\left./ \mathrm{m}^{2}-{ }^{\circ} \mathrm{C}\right)$ 


\section{FIGURES}

FIG. 1

Typical Solar Energy Collection System and Controller Block Diagram (XBL 7912-13329)

FIG. 2

On/Off Controller Diagram (XBL 7912-13326)

FIG 3.

Proportional Controller Diagram (XBL 7912-13330)

FIG. 4.

Typical Cycling Sequence Generated by Dynamic Collector Model (XBL 7911-13120)

FIG. 5. Tube and Fluid Element (XBL 7912-13327)

FIG.6. Isolation Patterns for Clear Days (XBL 7912-13325)

FIG. 7. Insolation Pattern for Cloudy Day (XBL 7912-13324)

FIG.8. Ambient Temperature Profiles (XBL 7912-13323)

\section{$\underline{\text { TABLES }}$}

TABLE 1. SUMMARY OF COLLECTOR PARAMETERS AND SIMULATION RUNS

TABLE 2. CONTROLLER STRATEGY COMPARISONS

TABLE 3. CONTROLLER STRATEGY COMPARISONS INCLUDING PUMPING POWER

TABLE 4. COMPARISON BETWEEN STEADY-STATE AND DYNAMIC MODEL EFFICIENCY PREDICTIONS

TABLE 5. CONTROLLER STRATEGY COMPARISONS FOR COLD SLUG AT INLET 
